\title{
Environmental Awareness and Adoption Intention of Electric Cars in Young Adult
}

\author{
Khwanjira PONSREE ${ }^{\mathrm{a}, \mathrm{b}}$, Nathatenee GEBSOMBUT ${ }^{\mathrm{a}, \mathrm{b}}$, Vorrapol PAIYASEN ${ }^{\mathrm{a}}$, Tanat \\ ARCHARIYAPIBAL ${ }^{\mathrm{a}}$, Sedthawut SRICHIANGWANG ${ }^{\mathrm{a}}$, Santi NEE ${ }^{\mathrm{a}}$ and Phaninee \\ NARUETHARADHOL ${ }^{\mathrm{a}, \mathrm{b} 1}$ \\ anternational College, Khon Kaen University, Thailand \\ ${ }^{\mathrm{b}}$ Global Entrepreneurship Development Center, Khon Kaen University, Thailand
}

\begin{abstract}
The world is being heavily polluted, which is contributing to many natural disasters. Attempts are being made to come up with innovations that lessen the impact of pollution. Electric cars are one such innovation. Here we investigate the awareness of and decision making about buying electric vehicles among 204 young adults. We propose that consumer decisions related to several factors, which include global warming, air pollution, electric cars, travel and socialization, green self-identity of young adults, and intentions on the use of electric cars. This research was able to show that independent variables can affect consumer awareness and decision making towards the purchase or adoption of electric cars.
\end{abstract}

Keywords. Young adult, electric car, environmental awareness, eco-friendly

\section{Introduction}

Over 100 years ago, the electric car was initially introduced to the United States, Hungary, and the Netherlands as an option to reduce the dependency of steam-based and gasoline-based power. By the beginning of the 1970s, the electric car had emerged as an innovative option for customers, particularly in the United States, as a means to avoid the possible and unprecedented oil shortage as a result of the oil crisis in the Middle East, as well as to help reduce the emission of carbon dioxide $\left(\mathrm{CO}_{2}\right)$ [1].

Although many questions have been raised regarding the reliability of statistic environmental awareness, the data collected from. Participants with diverse background showed differences interesting point of views. Concerning the market adoption of this technology, data on global warming, air pollution, travel socialization, green self-identity was needed. Here we investigate young adults' intention to use an electric car and explore their awareness of electric cars and the factors that affect their decision making in purchasing electric cars.

Participants were asked, "How can electric cars solve the global warming crisis?" and "Do they see positive or negative potentials of the electric car?". This analytical research, therefore, was created to explore the perception and decision-making of young adult consumers and to assess the awareness of this innovative product. Also, this research assesses the current and future position of electric vehicles, and whether it

1 Corresponding Author: Phaninee NARUETHARADHOL, International College, Khon Kaen University; Global Entrepreneurship Development Center, Khon Kaen University, Thailand; Email: phaninee@kku.ac.th 
is justified for consumers to purchase the product. By estimating consumer evaluations via questionnaires, this research should shed some light on consumers' perception of electric cars and how likely they are to purchase an electric car.

\section{Literature review}

\subsection{Electric car}

The rising number of personal cars in cities and towns is creating traffic congestion, parking problems, and noise pollution. Personal vehicles are parked for very long hours, so there are secondary usage levels. Vehicle sharing programs are structured on multiple-person pooled usage of cars, and the use rate of such automobiles, typically operated by corporations or organizations, is far higher than private vehicles. Typically, they serve their users following a subscription scheme and charge use through distance or time traveled. Because of this, sort of consumers prefers to travel less frequently. Car-share programs, coupled with the introduction of environmentally sustainable cars, can reduce these critical community concerns.

Depending on whether passengers are expected to enter those stations or not, carshare programs can be divided into two types, station-dependent and free-roaming. Two categories of trips can be found in station-based, car pick-up programs. Round trips require more abandoned stations, while one-way trips require more dumped stations. One-way systems provide users with greater versatility but require more complex maintenance because severe load imbalances can occur at stations. The cars can be placed anywhere inside a predefined zone in free-floating structures, so consumers can choose the vehicles from within the zone they are positioned. Per the emergence of interests from a versatility standpoint, the free-floating models are unable to affirm consumers that there is sufficient parking space available for them at the destination, and vehicles necessarily need to be stopped at the place where there is sufficient petrol or electricity. Also, such networks usually involve car movement to match the supply in various areas in town as well as to conduct operations either on refueling or recharging [2].

Power protection and urban air emissions concern, resulted from operations of automobile production, are becoming progressively more severe [3]. With transport cars, for example, toxic tailpipe pollution has become a troublesome environmental issue, of which battery-electric vehicles (BEVs) can be an alternative solution. Besides, the BEV market share remains small because of restricted all-electricity (AER) drawbacks, nuisance charging, high upfront costs, and security issues [4]. Of these, battery-electric cars (BECs) would need a long AER to be acceptable to consumers. There have been recent significant and incremental changes in BEC's AER and an increase in the battery pack capacity. In the future, super-fast charging (thereby shortening the charge time of long-range BECs) is likely to be realized. Such a phenomenon connected to the production of more powerful HPCs has recently prompted several national governments to draw up a technical strategy to build and improve super-HPCs for electric cars [5]. 


\subsection{Methods for modeling the use of electric vehicles}

Among available survey methods, activity-based modeling (ABM) offers a framework for fusing cross-sector studies [6]. This is needed for advancing the integration between transportation and electricity networks. However, there is the limitation to this mode as the behavioral changes of the users are difficult to measure. Per the study of this research, this said model can be employed to explore people's intentions and awareness towards the importance of the use of the electric car in the context of global warming.

\subsection{Green self-identity}

By identity theories, self-identity is the primary motivating factor underlying behavior [7]. The study was adopting a sociological personality strategy [8]. It is also known for a definitional collection in supporting their positions. The essence of identification is to imagine oneself in a role and to integrate the values and self-expectations. Those values and definitions then form a collection of criteria that govern actions [9]: by taking a position of identification, people take expectations that follow the function, and then behave in a way that embodies and maintains those expectations [10]. The higher of the equal prominence, the more the individual participate in acts that enforce their uniqueness [11]. Consequently, the self-identification of a customer (i.e., whether people understand themselves concerning different roles) is an independent indicator of perceptions and consumer habits, since consumers pursue conformity with the identification norm by interpersonal acts [12].

\subsection{Environmental awareness}

The impact of consumption on the environment is the reflecting of a concept of consequentialist on the degree to which customers are alert to the ecological implications of their use [13]. In reality, customers will buy goods based on the degree to which they are concerned about how the use of such things affects the biological environment [14]. Environmental awareness, in this respect, also affects the purchasing intention of environmental-friendly products [15]. Considering the environmental impact, they might interpret something as immoral and environmentally unfriendly. Responsibility for the ecological consequences of use is a profound notion reflecting how responsive customers are to the environmental implications of their consumption. The values of universalism are of greater interest in such persons, such as the protection of the environment and peace of nature [14].

\subsection{Green moral obligation}

Ethical science, users continue to focus on the philosophical principles of teleology and deontology to form their behavior in ethical circumstance [16]. Green moral responsibility is noted as the degree that a person recognizes the negative moral aspects of adopting specific products that damage the environment. Green moral obligation can be described as a personal internal state construct (that) concerns the degree to which an entity feels a sense of duty to behave when confronted with an ethical circumstance, such as protection of the environment. This notion is following the norm activation paradigm, where pro-social conduct is supposed to emerge from personal expectations that represent senses of moral obligation to undertake or refrain from acts. Customers 
should keep within an eco-friendly best practice. Ultimately, the infringement of such values is wrong [17]. These results suggest that environmental self-identity is linked with an obligation-based intrinsic desire to behave for the world, which its effect arbitrates the linkage between environmental self-identity and environmentally sustainable behavior. In the United States, for example, the declaration of the 1990 Clean Air Act Amendment and the 1992 Energy Policy Act was noted as the regulation that signified the regulations concerning the transportations emissions sparking the raising of awareness among American public concerning the alternative vehicle to help reduce the carbon emission that affected the global warming issue [1]. Taking all the above into account, this research distinguishes green moral obligation from the context of the US by considering, among young adult Thai citizens, the sense of obligation towards environment impact caused by the high numbers of manufacturing and the use of non-eco-friendly options.

\subsection{Intention to adopt eco-friendly habits}

When purchasing and embracing environmentally sustainable electric vehicles, this research claims that the more people view themselves as green customers, the more they have a social obligation to reduce their use of environmentally unfriendly products. The further optimistic their views about the introduction of eco-sustainable electric vehicles, the more likely they are to purchase such goods [18].

\section{Hypotheses}

- Hypothesis 1: Green self-identity positively estimates environmental awareness.

- Hypothesis 2: Green self-identity positively influences a green moral obligation.

- Hypothesis 3: Environmental awareness positively impacts the attitude towards the adoption of electric cars.

- Hypothesis 4: Moral obligation positively impacts attitude towards the adoption of electric cars.

- Hypothesis 5: Attitude towards the adoption of electric cars positively estimate the evaluation of electric cars.

- Hypothesis 6: Evaluation of electric cars positively influence the intention to adopt an electric car.

- Hypothesis 7: Green self-identity positively impacts the evaluation of electric cars.

\section{Research Methodology}

\subsection{Sampling}

The data were collected through an online survey with information written in both Thai and English, and through a social media platform, requesting informants to fill out their 
details to make more understanding which is to make result receive high satisfaction so that this research can test hypothesized relationships towards those variables in the proposal of this research model. The study participants are young adults between 19 and 36 years old. As of February 2020, 208 young adults have responded to the survey. Most of the respondents are males between 18 and 23 years old and who are currently studying bachelor's degrees. Respondents' salaries were mostly less than 10,000 baht per month. Also, their career is mostly student. Four respondents not within the target group were excluded from our analyses. The sample characteristics are present in Table 1 .

The survey was designed into two parts. Part 1 addresses the respondents' demographics (gender, age, education, salary, and career). Answers involved assigning ratings from one to five or multiple choice. On the other hand, in terms of specific detail, there are green self-identify, environmental awareness, green moral obligation, attitude towards the adaptation of electric cars, evaluation of electric cars, and intention to adopt electric vehicles. In each of these, this research has three sub-questions for those sampling to answer for the satisfaction of it, which is a five-point Likert scale, ranging from "(1) Dissatisfied" to "(5) Satisfied" strongly disagree, disagree, so-so, agree, strongly agree. This research has adapted the previous research that related to the research study in making the result to be more satisfactory [19].

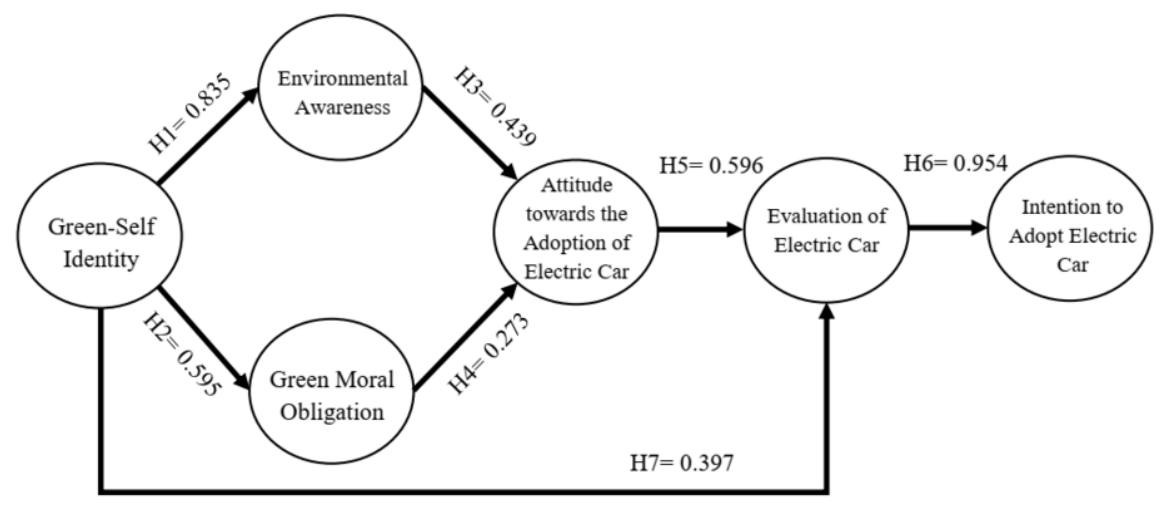

Figure 1. Structural model results.

Table 1. Sample characteristics $(n=204)$.

\begin{tabular}{|c|c|c|c|c|c|c|}
\hline Measure & $\begin{array}{l}\text { Freque } \\
\text { ncy }\end{array}$ & $\begin{array}{l}\begin{array}{l}\text { Perc } \\
\text { ent }\end{array} \\
\end{array}$ & Measur & & $\begin{array}{l}\text { Freque } \\
\text { ncy }\end{array}$ & $\begin{array}{l}\text { Perc } \\
\text { ent }\end{array}$ \\
\hline Gender & & & Salary & & & \\
\hline Male & 104 & 51 & $\begin{array}{r}\text { Below } \\
10,000 \text { baht }\end{array}$ & & 102 & 50 \\
\hline Female & 100 & 49 & $\begin{array}{r}10,001 \\
50,000 \text { baht }\end{array}$ & - & 94 & 46.1 \\
\hline Age (year old) & & & $\begin{array}{r}50,001 \\
80,000 \text { baht }\end{array}$ & - & 4 & 2 \\
\hline $18-23$ & 174 & 85.3 & $\begin{array}{r}\text { Above } \\
80,000 \text { baht }\end{array}$ & & 4 & 2 \\
\hline
\end{tabular}




\begin{tabular}{|c|c|c|c|c|c|}
\hline Measure & $\begin{array}{l}\text { Freque } \\
\text { ncy }\end{array}$ & $\begin{array}{l}\text { Perc } \\
\text { ent }\end{array}$ & Measure & $\begin{array}{l}\text { Freque } \\
\text { ncy }\end{array}$ & $\begin{array}{l}\text { Perc } \\
\text { ent }\end{array}$ \\
\hline $24-29$ & 21 & 10.3 & & & \\
\hline $30-35$ & 7 & 3.4 & $\begin{array}{c}\text { Career } \\
\text { Student/ } \\
\text { College student }\end{array}$ & 169 & 82.8 \\
\hline $36-39$ & 2 & 1 & $\begin{array}{l}\text { Personal } \\
\text { business }\end{array}$ & 9 & 4.4 \\
\hline Education & & & $\begin{array}{l}\text { Governme } \\
\text { nt Employee }\end{array}$ & 8 & 3.9 \\
\hline $\begin{array}{l}\text { Senior } \\
\text { High School and } \\
\text { under }\end{array}$ & 9 & 4.4 & $\begin{array}{l}\text { Office } \\
\text { employee }\end{array}$ & 10 & 4.9 \\
\hline $\begin{array}{l}\text { Vocational } \\
\text { Certificate, or } \\
\text { Diploma }\end{array}$ & 5 & 2.5 & Other & 8 & 3.9 \\
\hline $\begin{array}{l}\text { Bachelor's } \\
\text { degrees }\end{array}$ & 184 & 90.2 & & & \\
\hline $\begin{array}{l}\text { Above } \\
\text { bachelor's } \\
\text { degrees }\end{array}$ & 6 & 2.9 & & & \\
\hline
\end{tabular}

Table 2. Factor loadings and CR and AVE values.

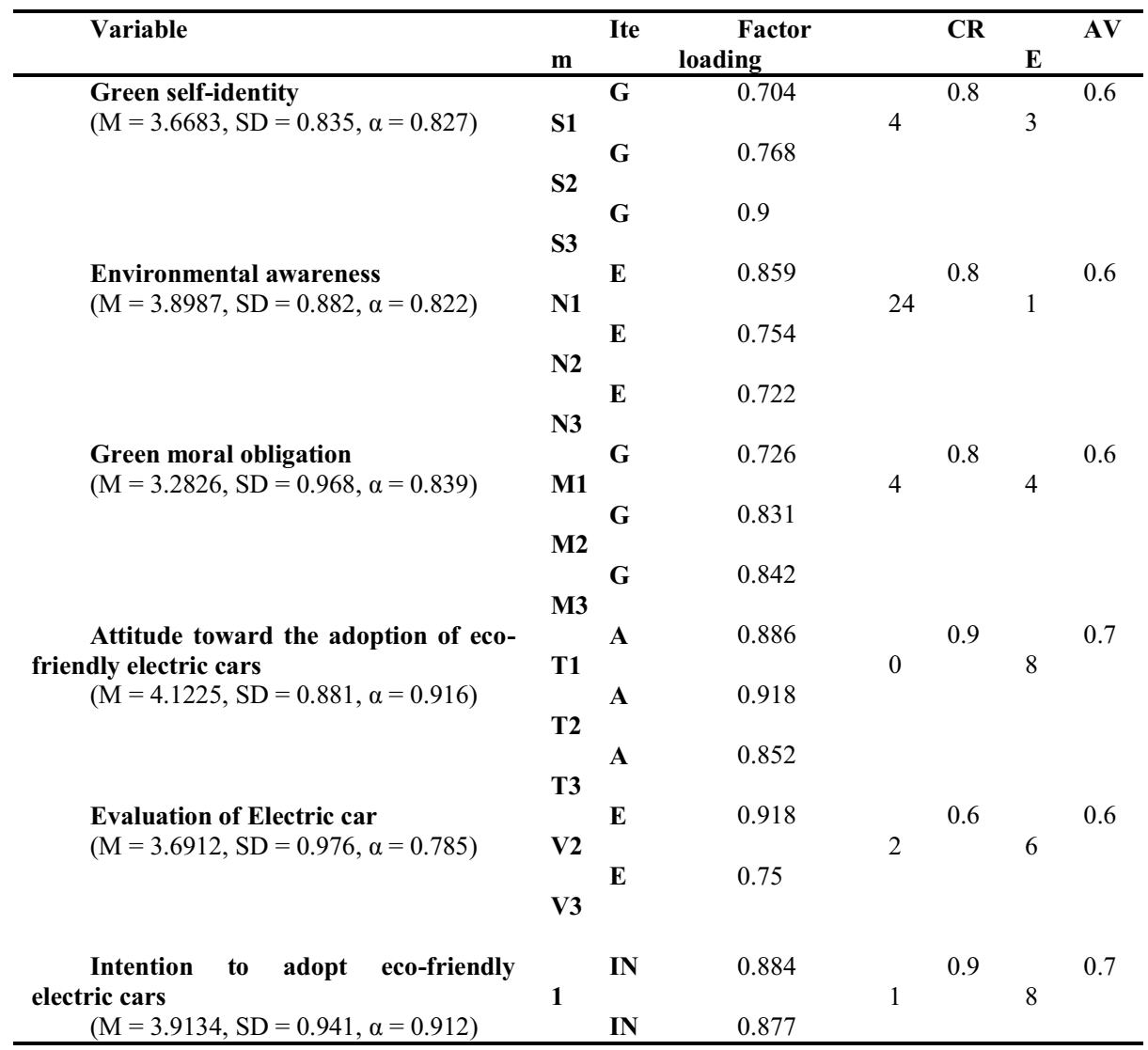




\begin{tabular}{llcccc}
\hline Variable & & Ite & $\begin{array}{c}\text { Factor } \\
\text { loading }\end{array}$ & CR & AV \\
\hline & $\mathbf{2}$ & & & \\
& & IN & 0.881 & \\
\hline
\end{tabular}

Table 3. Correlation matrix of the critical variables.

\begin{tabular}{|c|c|c|c|c|c|c|c|c|c|c|}
\hline & & GS & & EN & & GM & & AT & EV & IN \\
\hline GS & & 1 & & & & & & & & \\
\hline \multirow[t]{2}{*}{ EN } & & 0.61 & & 1 & & & & & & \\
\hline & 4 & & & & & & & & & \\
\hline \multirow[t]{2}{*}{ GM } & & 0.48 & & 0.40 & & 1 & & & & \\
\hline & 8 & & 9 & & & & & & & \\
\hline \multirow[t]{2}{*}{ AT } & & 0.45 & & 0.45 & & 0.35 & & 1 & & \\
\hline & 2 & & 4 & & 4 & & & & & \\
\hline \multirow[t]{2}{*}{ EV } & & 0.52 & & 0.42 & & 0.38 & & 0.75 & 1 & \\
\hline & 3 & & 7 & & 1 & & 7 & & & \\
\hline \multirow[t]{2}{*}{ IN } & & 0.55 & & 0.48 & & 0.35 & & 0.70 & 0.85 & 1 \\
\hline & 2 & & 8 & & 7 & & 0 & & & \\
\hline
\end{tabular}

Table 4. Result and goodness-of-fit indices.

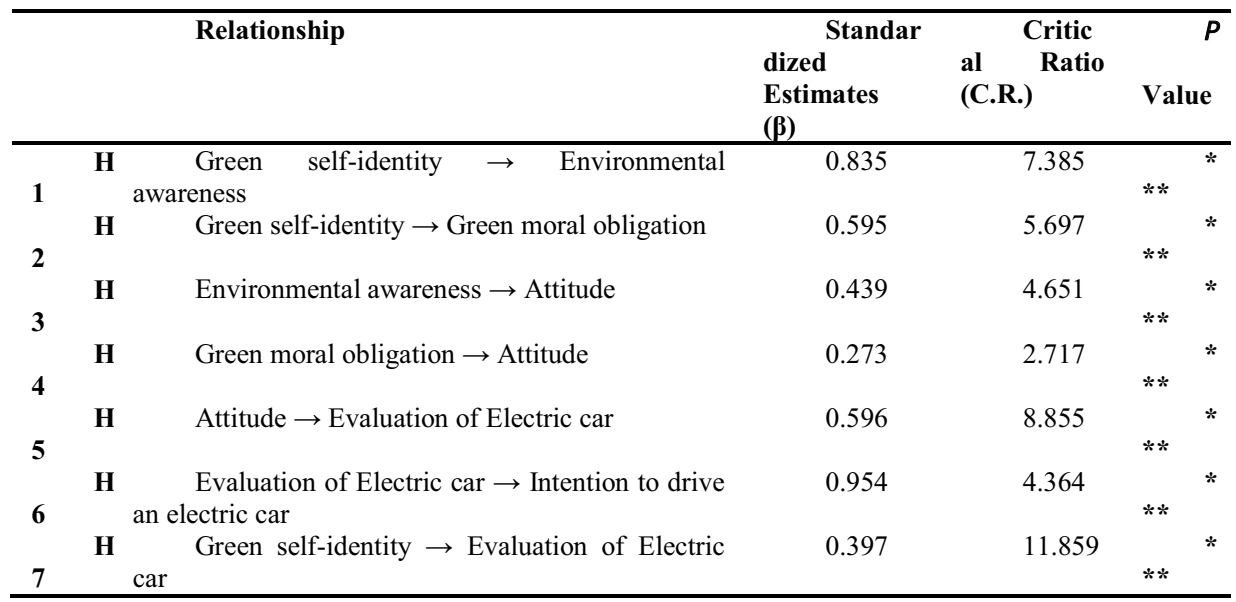

\section{Results}

This research model was tested using SPSS version 26 and AMOS 26. The mean, standard deviation, and alpha values were calculated using SPSS. For factor loading, composite reliability (CR) and average variance extract (AVE) were computed using AMOS. Before testing the relationship of assumptions, this research analyzed the reliability and accuracy of the scale. Legality has been inspected which shows that the 
items are related to each other. The sample characteristics are present in Table 1. The sample characteristics are present in Table 1.

Furthermore, whether they are in the same scope or not, the lower acceptable values are 0.70 for $C R$ and 0.50 for AVE [20] (Table 2). The CR of each variable is more significant than 0.8 . The AVE of each variable was higher than 0.50 , which means the completion of convergence. Table 3 shows that all variables have a significant correlation with each other as these correlations can be explained as the moderate and robust levels because of the correlation coefficients ranging from 0.30 and above, indicating strength and direction of positive association.

In terms of results and goodness-of-fit indices, there are Standardized Regression Weights, C.R., which Critical Ratio and p-value explain ${ }^{*} \mathrm{p}<0.05,{ }^{*} \mathrm{p}<0.01, * * * \mathrm{p}<$ 0.001 in each of relation of it or hypothesis. Thus, we found that all hypotheses were statistically significant.

First, H1 (when young adults identify themselves as an environmentally friendly consumer, it leads to them having environmental awareness) was confirmed $(\beta=0.83$, $\mathrm{p}<0.001)$. Next, we found that when young adults identify themselves as an environmentally friendly consumer, it leads to more green moral obligation. So, H2 was also supported $(\beta=0.59, \mathrm{p}<0.001)$. Following this, when young adults have environmental awareness, it leads to an attitude towards the adaptation of electric cars. H3 was positive $(\beta=0.43, \mathrm{p}<0.001)$. Besides, $\mathrm{H} 4$ was supported; that when young adults have a green moral obligation, it leads to an attitude towards the adaptation of electric cars $(\beta=0.27, \mathrm{p}<0.001)$. H5 has a positive influence on young adults with an attitude towards the adaptation of electric cars $(\beta=0.59, \mathrm{p}<0.001)$. H6 (when young adults evaluate electric cars, it leads to the intention to adopt an electric car) $(\beta=0.95$, $\mathrm{p}<0.001$ ) and H7 (when young adults self-identify as an environmentally friendly consumer, it gives a positive evaluation of electric cars $)(\beta=0.39, \mathrm{p}<0.001)$ were also supported.

The goodness-of-fit of Confirmatory Factors Analysis (CFA) indices show that the model did fit the data at a higher level: $\chi 2$ /d.f. $=1.804 ; \mathrm{p}<0.001$; GFI $=0.9$; AGFI $=0.853 ; \mathrm{CFI}=0.962 ;$ RMSEA $=0.063$. On the other hand, the goodness-of-fit of Structural Equation Modeling (SEM) indices indicate the model did fit the data: $\chi 2$ /d.f. $=1.795 ; \mathrm{p}<0.001 ; \mathrm{GFI}=0.893 ; \mathrm{AGFI}=0.854 ; \mathrm{CFI}=0.96$; $\mathrm{RMSEA}=0.063$.

\section{Conclusion}

This research This study aimed to examine the awareness, including the decision making of young adults concerning electric cars, through the research model titled of the information acceptance model or IACM. The online survey for those sampling to answer precisely. This research engaged with 204 people through an online platform for sampling (after four respondents were excluded). Most of the respondents were interested in electric cars, were male, and 18-23 years old. They were mostly students studying their bachelor's degrees.

Moreover, most of the respondents have a salary of less than 10,000 baht per month. The respondents had high levels of awareness which proved their decision making to purchase the electric car, due to p-values that are significant in each relation of hypothesis. All of the proposed hypotheses were accepted. Most of the people who identify themselves as an environmental-friendly person are indeed interested in adopting a new innovative product, such as electric cars. Due to their moral obligations 
and better environmental awareness, it helps an individual's decision making for choosing their superior electric and future cars. While another research mention that primary sources of information and motivations are the essential points for people to select an electric vehicle [21]. Each young adult might prefer different ways of creating their awareness and decision making. The rational model is a logical system, which the problem will be identified before an individual generating alternative solutions [22]. For the Bounded Rationality Model, it is about creating the expression bounded rationality to explain an individual's decision-maker who tries to find the best decisions whereas end up with the decision making [23]. Therefore, both models will allow young adults to make their final decision of using the electric car.

Moreover, the policy will be another way of raising people's awareness in the country. [1] The U.S. Department of Transportation has promoted Corporate Average Fuel Economy (CAFE) Standards since 1975, encouraging people to use the vehicles that save fuel and reduce energy consumption.

This study has some limitations. The research explored only or mostly young adults in Khon Kaen, Thailand. The responders were fairly homogenous and not representative of the whole society. Furthermore, the topic of electric cars is relatively new, and still is not accessible within the selected area. Therefore, there were only a few people that were well-informed about electric cars. Therefore, we would advise future researchers to collect data from multiple, diverse populations. Lastly, the findings reported here are will likely be useful for manufactures when designing electric car marketing campaigns.

\section{Acknowledgement}

This research was partially supported by Khon Kaen University International College (KKUIC). We thank our colleagues from Khon Kaen University International College and Global Entrepreneurship Development Center, Khon Kaen University who provided insight and expertise that greatly assisted the research.

\section{References}

[1] Rebecca M. The History of Electric Car [Internet]. U.S. Department of Energy. 2014 [cited 2020 Feb 9]. Available from: https://www.energy.gov/articles/history-electric-car\#: :text=Here in the U.S.\%2C the,spark interest in electric vehicles.

[2] Calik H, Bernard F. A Benders Decomposition Method for Locating Stations in a One-Way Electric Car Sharing System under Demand Uncertainty. Transp Res Part B. 2019;125:121-50.

[3] Jun Y, Liu N, Wang G, Zhang W, Yun J, Chen Z. How Much Can Behavioral Targeting Help Online Advertising? In: the 18th International Conference on World Wide Web. 2009. p. 261-70.

[4] Śledzik K. Schumpeter's View on Innovation and Entrepreneurship. Ssrn. 2013;(April 2013).

[5] Groot J, Swierczynski M, Stan AI, Kær SK. On the complex ageing characteristics of high-power LiFePO4/graphite battery cells cycled with high charge and discharge currents. J Power Sources [Internet]. 2015 Jul;286:475-87. Available from: https://linkinghub.elsevier.com/retrieve/pii/S0378775315006229

[6] Daina N, Sivakumar A, Polak JW. Modelling electric vehicles use: a survey on the methods. Renew Sustain Energy Rev [Internet]. 2017 Feb;68:447-60. Available from: https://linkinghub.elsevier.com/retrieve/pii/S1364032116306566

[7] Stryker S, Burke PJ. The Past, Present, and Future of an Identity Theory. Soc Psychol Q [Internet]. 2000 Dec;63(4):284. Available from: http://www.jstor.org/stable/2695840?origin=crossref 
[8] Stets JE, Burke PJ. A Sociological Approach to Self and Identity * A Sociological Approach to Self and Identity Thoughts on Social Structure. Handb Self Identity [Internet]. 2003;(January 2003):128-52. Available from: http://wat2146.ucr.edu/papers/02a.pdf

[9] Stets JE, Burke PJ. Identity theory and social identity theory. Soc Psychol Q. 2000;63(3):224-37.

[10] Grubb EL, Grathwohl HL. Consumer Self-Concept, Symbolism and Market Behavior: A Theoretical Approach. J Mark [Internet]. 1967 Oct;31(4):22. Available from: https://www.jstor.org/stable/1249461?origin=crossref

[11] Jan E. Stets, Chris F. Biga. Bringing Identity Theory into Environmental Sociology. Sociol Theory [Internet]. 2003;21(4). Available from: https://journals.sagepub.com/doi/10.1046/j.14679558.2003.00196.x

[12] Steven Arnockya, Mirella Stroinkb, Teresa DeCiccoc. Self-construal predicts environmental concern, cooperation, and conservation. Environ Psychol [Internet]. 2007;27(4). Available from: https://www.sciencedirect.com/science/article/abs/pii/S0272494407000527?via\%3Dihub

[13] André Hansla, Amelie Gamble, Asgeir Juliusson, Tommy Gärling. The relationships between awareness of consequences, environmental concern, and value orientations. Environ Psychol [Internet]. 2008;28(1). Available from: https://www.sciencedirect.com/science/article/abs/pii/S0272494407000576?via\%3Dihub

[14] William Kilbourne, Gregory Pickett. How materialism affects environmental beliefs, concern, and environmentally responsible behavior. Bus Res [Internet]. 2008;61(9). Available from: https://www.sciencedirect.com/science/article/abs/pii/S0148296307002913?via\%3Dihub

[15] Oliver M. Freestone, Peter J. McGoldrick. Motivations of the Ethical Consumer. Bus Ethics [Internet]. 2008; Available from: https://link.springer.com/article/10.1007/s10551-007-9409-1

[16] Scott J. Vitell, James Lewis Thomas, Anusorn Singhapakdi. Consumer Ethics: An Application and Empirical Testing of the Hunt-Vitell Theory of Ethics. Consum Mark [Internet]. 2001; Available from:https://www.researchgate.net/publication/235317711_Consumer_Ethics_An_Application_and _Empirical_Testing_of_the_Hunt-Vitell_Theory_of_Ethics

[17] John Peloza, Katherine White, Jingzhi Shang. Good and Guilt-Free: The Role of SelfAccountability in Influencing Preferences for Products with Ethical Attributes. Marketing [Internet]. 2013; Available from: https://journals.sagepub.com/doi/10.1509/jm.11.0454

[18] Camilla Barbarossa, Suzanne C.Beckmann, PatrickDe Pelsmacker, IngridMoons, Wencke Gwozdzd. A self-identity based model of electric car adoption intention: A cross-cultural comparative study. Environ Psychol [Internet]. 2015; Available from: https://doi.org/10.1016/j.jenvp.2015.04.001

[19] Aihui Chen, Yaobin Lu, Bin Wang, Show more. Customers' purchase decision-making process in social commerce: A social learning perspective. Inf Manag [Internet]. 2017;37(6). Available from: https://doi.org/10.1016/j.ijinfomgt.2017.05.001

[20] Fornell C, Bookstein FL. Partial Least Squares Estimation in Structural Equations,. 1981.

[21] Williams B, Johnson C. E.V. Consumer Characteristics, Awareness, Information Channels \& Motivations". Center for Sustainable Energy [Internet]. Center for Sustainable Energy. 2016. Available from: https://energycenter.org/sites/default/files/ docs/ext/transportation/2016-07-20 EVR9-CSEPEVmarkets handout.pdf

[22] Lunenburn FC. The Decision-Making Process. Natl FORUM Educ Adm Superv J. 2010;27(4).

[23] Simon HA. Rational Decision Making in Business Organizations. Am Econ Rev [Internet]. 1979;69(4):493-513. Available from: https://www.jstor.org/stable/1808698 